\title{
PERANCANGAN SISTEM INFORMASI MANAJEMEN BERBASIS WEB STUDI KASUS : PT UNICORN INTERTRANZ
}

\author{
Ghavinkson Enstayn Abednego Kustanto*1, Hanna Prillysca Chernovita ${ }^{2}$ \\ ${ }^{1,2}$ Universitas Kristen Satya Wacana \\ Email: $1682017154 @$ student.uksw.edu, ${ }^{2}$ hanna.chernovita@uksw.edu \\ *Penulis Korespondensi
}

(Naskah masuk: 17 Maret 2021, diterima untuk diterbitkan: 19 Juli 2021)

\begin{abstract}
Abstrak
Pengelolaan data perusahaan merupakan suatu hal utama dan krusial dalam memasuki persaingan industri era sekarang. Selain mudah dan aman, sistem manajemen yang telah terintegrasi dengan komputer (komputerisasi) dapat meminimalkan risiko human error. Dalam perancangan sistem informasi manajemen sendiri terdapat banyak metode yang dapat dipakai, salah satunya adalah metode prototype. Metode prototype memudahkan client untuk melihat dan mengevaluasi prototype secara bertahap seiring program dibangun. Prototype dapat ditambah maupun dikurangi sesuai keinginan client selama proses pengembangan berlangsung. Metodologi prototype memiliki beberapa tahapan yaitu, communication, quick planning, quick Modelling, construction hingga deployment. Adapun tujuan penelitian ini ialah melakukan perancangan sistem informasi manajemen perusahaan untuk mendukung aktivitas bisnis serta pengelolaan data perusahaan. Sistem informasi manajemen yang akan dibangun pada perusahaan ini meliputi komputerisasi seluruh proses bisnis, desain sistem pada setiap divisi, hingga perancangan database perusahaan. Perancangan sistem informasi ini dimulai dari pengumpulan data yang diperlukan menggunakan metode diskusi dan wawancara, penerjemahan data ke dalam UML diagram, implementasi kode sistem, hingga testing.
\end{abstract}

Kata kunci: Perusahaan, Sistem Informasi Manajemen, Prototype, Web

\section{WEB-BASED MANAGEMENT INFORMATION SYSTEM DESIGN CASE STUDY: PT UNICORN INTERTRANZ}

\begin{abstract}
Management of company data is a major and crucial thing in entering today's industrial competition. Apart from being easy and safe, a computerized management system can minimize the risk of human error. In designing the management information system itself, there are many methods that can be used, one of which is the prototype method. The prototype method makes it easy for clients to see and evaluate the prototype in stages as the program is built. Prototypes can be added or subtracted according to the development process. The stages in the prototype methodology include communication, quick planning, quick modelling, construction and deployment. The purpose of this research is to design a company management information system to support business activities and company data management. The management information system that will be built in this company includes computerization of all business processes, system design in each division, to designing company databases. The design of this information system starts from collecting the necessary data using discussion and interview methods, translating data into UML diagrams, implementing system code, to testing.
\end{abstract}

Keywords: Company, Management Information System, Prototype, Web

\section{PENDAHULUAN}

Pesatnya perkembangan teknologi telah mengantarkan manusia ke era baru perindustrian yaitu industri 4.0. Telah menjadi rahasia umum bahwa perkembangan teknologi di era ini memberikan banyak dampak positif bagi bidang industri perusahaan. Banyaknya software, sistem, dan teknologi baru yang mendukung aktivitas- aktivitas perusahaan terus bermunculan. Mulai dari yang sangat mendasar seperti aplikasi pemrosesan data, beranjak ke sistem yang dapat membantu pengambilan keputusan, hingga teknologi kecerdasan buatan yang sangat fenomenal.

Dengan adanya perkembangan teknologi yang pesat ini, sebagian besar perusahaan mulai terdorong untuk dapat menggunakan teknologi secara efektif dan efisien sebagai penunjang proses bisnis mereka. 
Akibatnya banyak bermunculan perusahaanperusahaan startup baru yang tentunya telah menggunakan teknologi sebagai bahan bakar utama. Disisi lain, perusahaan lama pun tidak mau kalah untuk turut menggunakan teknologi sebagai penunjang bisnis mereka, misalnya PT. Unicorn Intertranz.

PT. Unicorn Intertranz merupakan suatu perusahaan dibidang jasa pengiriman barang yang telah beroperasi selama kurang lebih delapan tahun. Perusahaan ini berlokasi di Greenlake Tangerang dan telah memiliki lebih dari 20 customer yang terdiri dari beberapa pabrik perusahaan besar di Indonesia seperti PT. Inbisco Niagatama Semesta (Mayora Group), PT. Tiki Jalur Nugraha Ekakurir (JNE), dan pabrik Domino Pizza Indonesia.

Proses bisnis perusahaan ini cukup kompleks, mulai dari penerimaan data pengantaran barang atau Delivery Order (DO) hingga publikasi tagihan invoice perusahaan ke customer. Sekalipun telah dilakukan pembagian divisi, namun seluruh proses bisnis serta aktivitas perusahaan masih dilakukan secara manual serta belum adanya sistem yang terintegrasi antar divisi pada perusahaan, mengakibatkan sering terjadi misscommunication dan human error pada perusahaan ini. Hal ini tentunya menghambat proses bisnis dan dapat menimbulkan dampak yang fatal bagi perusahaan.

Oleh sebab itu, diperlukan perancangan dan penerapan sistem informasi manajemen perusahaan untuk menjadi dashboard utama sebagai wujud komputerisasi proses bisnis dan penerapan teknologi yang mampu mempermudah perusahaan dalam menjalankan proses bisnis maupun aktivitas bisnis lainnya.

Penelitian terdahulu yang serupa yakni Perancangan Sistem Informasi Manajemen Rumah Sakit Berbasis Web Studi Kasus : Rumah Sakit TNI AU Lanud Sam Ratulangi (Topan, M., Najoan, X. B, 2015) serta Rancang Bangun Sistem Informasi Pengelolaan Kendaraan di PT PLN (Persero) Area Mojokerto (Masrur, M., Mustofa, N. A., \& Sofanni, M, 2015). Perbedaan mendasar penelitian ini dengan penelitian terdahulu terletak pada cakupan perancangan sistem, studi kasus, serta metode yang digunakan.

\section{METODE PENELITIAN}

Mengacu pada metodologi prototyping, setiap sub metode dilakukan dengan cermat dan tertata berdasarkan rancangan kegiatan yang telah dibuat, dengan memperhatikan setiap urutan metode secara teliti. Adapun alur penerapan metodologi prototyping yang dituangkan ke dalam flowchart terdapat pada gambar 1 .

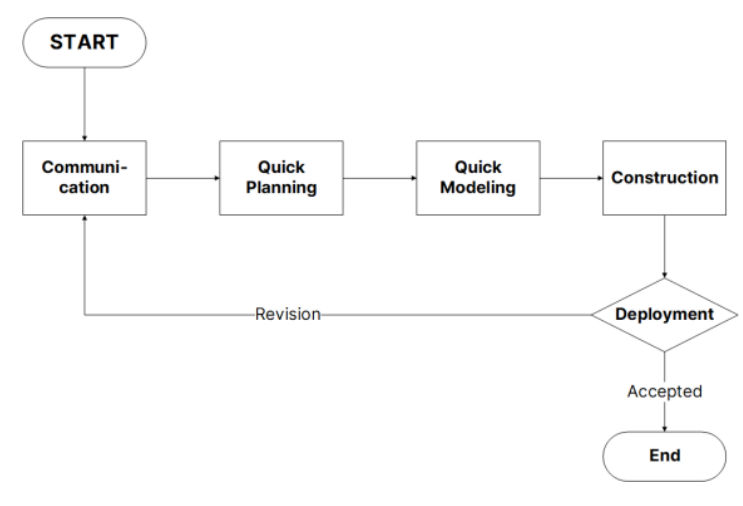

Gambar 1. Flowchart Metode Penelitian Prototyping

\subsection{Communication}

Pada tahap ini, dilakukan diskusi dan pengumpulan data perusahaan sebagai langkah awal dalam menganalisis kebutuhan sistem. Narasumber pada diskusi ini antara lain Direktur perusahaan, kepala divisi Invoice, dan beberapa karyawan perusahaan. Hasil dari tahap ini ialah proses bisnis perusahaan yang telah dituangkan ke dalam activity diagram.

\subsection{Quick Planning}

Pada tahap ini, dilakukan penyusunan rencana kerja sebagai acuan dalam pengembangan sistem perusahaan PT. Unicorn Intertranz. Hasil rencana kerja terdapat pada tabel 1 .

Tabel 1. Rencana Kerja

\begin{tabular}{|c|c|c|}
\hline No. & Kegiatan & $\begin{array}{c}\text { Estimasi waktu } \\
\text { Pelaksanaan }\end{array}$ \\
\hline \multicolumn{3}{|c|}{ Communication } \\
\hline & $\begin{array}{l}\text { Diskusi untuk mendapatkan data } \\
\text { kebutuhan perusahaan. }\end{array}$ & 2 hari \\
\hline \multicolumn{3}{|c|}{ Quick Planning } \\
\hline \multicolumn{2}{|c|}{ Quick Modeling } & 7 hari \\
\hline 3. & $\begin{array}{l}\text { Membangun desain dan mockup } \\
\text { sistem, beserta diagram. }\end{array}$ & 14 hari \\
\hline \multicolumn{3}{|c|}{ Construction } \\
\hline 4. & $\begin{array}{l}\text { Penulisan kode program dan } \\
\text { perancangan antarmuka sistem. }\end{array}$ & 3 bulan \\
\hline \multicolumn{3}{|c|}{ Deployment } \\
\hline & Demo dan penyerahan sistem & 1 bulan \\
\hline
\end{tabular}

\subsection{Quick Modelling}

Pada tahap ini, seluruh kebutuhan pengguna serta kebutuhan sistem informasi didefinisikan ke dalam beberapa diagram. Diagram-diagram yang digunakan antara lain activity diagram, usecase diagram, serta relational diagram.

\subsection{Construction}

Pada tahap ini, seluruh perancangan dan data terkait sistem yang akan dibuat diimplementasikan ke dalam struktur kode program komputer (coding). Dalam melakukan pengembangan sistem, bahasa pemrograman yang digunakan adalah php serta didukung teknologi javascript, ajax dan jQuerry. 
Komponen perangkat keras (hardware) dan perangkat lunak (software) yang digunakan dalam perancangan ini adalah sebagai berikut.

Hardware :

- $\quad$ Laptop ASUS

Software:

$\begin{array}{lll}\text { - } & \text { Sistem Operasi } & \text { : Windows 10,64 bit } \\ \text { - } & \text { Text Editor } & \text { : Microsoft VS. Code } \\ \text { - } & \text { Browser } & \text { : Google Chrome } \\ \text { - } & \text { DBMS } & \text { : MySQL } \\ \text { - } & \text { Server } & \text { : Xampp }\end{array}$

\section{LANDASAN TEORI}

\subsection{Sistem Informasi Manajemen}

McLeod dan Schell (dalam Mulyani S, 2017) mengatakan Management Information System adalah sebuah sistem yang sudah terkomputerisasi yang melakukan pengolahan data agar bisa digunakan oleh orang yang membutuhkannya. Sistem informasi manajemen merupakan komputerisasi proses bisnis sebab adanya interaksi antar manusia dan komputer. Sistem informasi manajemen memiliki cakupan fungsi yang cukup luas termasuk dalam menganalisis data dan risiko hingga pengambilan keputusan.

Sistem informasi manajemen sangat berperan penting dalam menunjang aktivitas bisnis perusahaan. Sistem yang terintegrasi serta praktis dapat mempermudah karyawan dalam menjalankan seluruh aktivitas perusahaan. Hal ini tentu menjadikan sistem informasi manajemen sebagai aset berharga bagi perusahaan. Disisi lain, perusahan menjadi unggul dalam bersaing ditengah perkembangan teknologi.

\subsection{Model Prototyping}

Ogedebe, dkk (2012), menyampaikan bahwa prototyping merupakan metode pengembangan perangkat lunak, yang berupa model fisik kerja sistem dan berfungsi sebagai versi awal dari sistem. Model prototyping ialah suatu teknik untuk mengumpulkan, merancang, serta membangun sebuah sistem berdasarkan kebutuhan-kebutuhan informasi secara cepat. Metode ini bertumpu pada penyajian hasil rancangan kepada client berupa prototype sistem. Prototype tersebut akan dievaluasi oleh client dan digunakan sebagai acuan dalam pengembangan sistem selanjutnya. Tahapan model pengembangan prototyping ini digambarkan pada gambar 2 .

\section{Communication (Komunikasi)}

Pada langkah ini, dilakukan analisa dan pengumpulan data terkait kebutuhan sistem yang akan dibangun melalui pertemuan dengan customer, serta pengumpulan data tambahan melalui jurnal, artikel, atau internet.

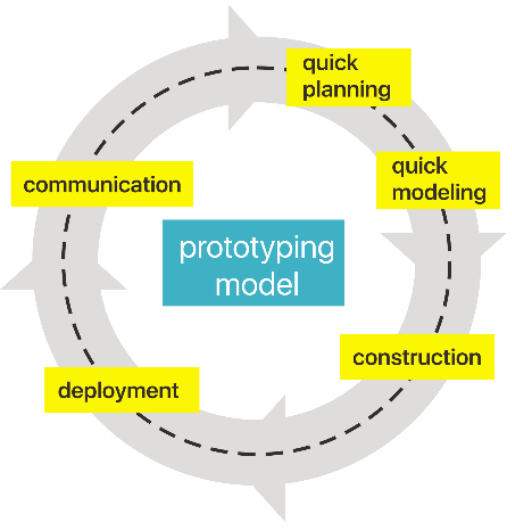

Gambar 2. Model Pengembangan Prototyping.

2. Quick Planning (Perencanaan cepat)

Pada tahap ini, perencanaan terhadap sistem manajemen perusahaan disusun dengan mempertimbangkan data yang telah dikumpulkan pada tahap komunikasi. Tahapan ini akan menghasilkan dokumen user requirement yang merupakan representasi dari seluruh kebutuhan perusahaan dalam pembuatan sistem, termasuk rencana kerja yang akan dilakukan.

\section{Quick Modelling (Pemodelan cepat)}

Pada tahap ini, dokumen user requirement dan data yang telah dikumpulkan kemudian dituangkan ke dalam suatu model atau mockup sistem sebelum diimplementasikan ke dalam struktur kode (coding). Tahap ini mengacu pada rancangan struktur data, rancangan fungsi software, rancangan interface, serta detail (algoritma) prosedural. Akhir dari langkah ini ialah pembuatan dokumen software requirement.

\section{Contruction (Konstruksi)}

Pada tahap ini, proses perangkaian struktur kode program (coding) dilakukan. Coding merupakan langkah penerjemahan desain dengan menggunakan bahasa yang bisa dikenali oleh komputer. Pada tahap ini programmer akan menerjemahkan setiap fungsi sistem yang diminta oleh user. Tahap ini merupakan tahap puncak dalam membangun suatu software, yakni penggunaan komputer sangat besar dalam langkah ini. Setelah melakukan coding, promgrammer akan melakukan testing. Testing bertujuan untuk menemukan kesalahan atau bug terhadap sistem/software yang telah dibangun untuk diperbaiki sebelum diserahkan kepada client.

\section{Deployment (Penyerahan)}

Merupakan langkah akhir dalam tahapan metode prototype. Setelah melewati tahap analisis, desain dan konstruksi, maka sistem yang telah rampung akan diserahkan kepada client. Client akan melakukan evaluasi terhadap prototype software 
yang telah dibuat termasuk melakukan diskusi terkait perbaikan serta pemeliharaan sistem.

\section{HASIL DAN PEMBAHASAN}

Setelah melakukan seluruh tahapan metodologi penelitian, berikut pembahasan hasil perancangan sistem informasi manajemen pada PT. Unicorn Intertranz.

\subsection{Model Perancangan Sistem}

\section{Usecase diagram}

Representasi aktivitas-aktivitas maupun interaksi dari pengguna dengan sistem. Usecase diagram perusahaan yang dibuat berdasarkan analisa sistem dapat dilihat pada gambar 3 .

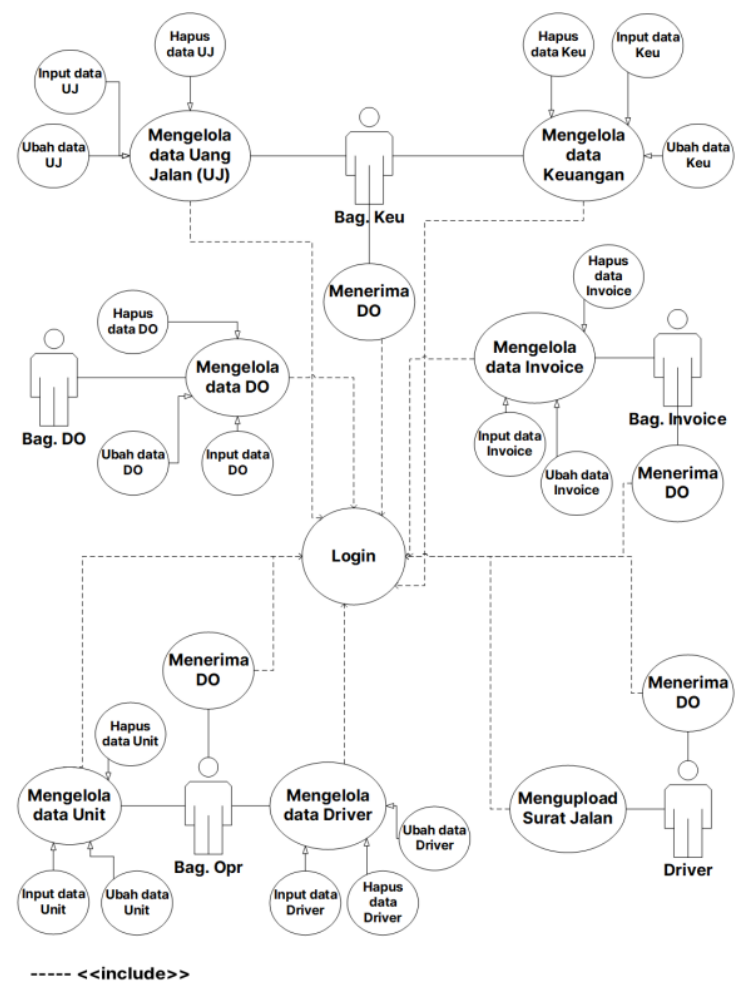

Gambar 3. Usecase diagram PT. Unicorn Intertranz

\section{Activity diagram}

Seluruh alur proses bisnis perusahaan secara berurutan dituangkan ke dalam diagram aktivitas atau activity diagram. Diagram ini akan menjadi acuan alokasi setiap privilege yang dimiliki user tiap divisi. Activity diagram perusahaan dapat dilihat pada gambar 4.

\section{Relational diagram}

Diagram yang digunakan untuk menggambarkan hubungan atau relasi antar entitas pada perancangan database sistem nantinya. Relational diagram perusahaan dapat dilihat pada gambar 5 .

\subsection{Model Protoype Sistem}

Prototype sistem yang akan dibangun dikategorikan ke dalam empat (4) sub sistem atau divisi, yakni Delivery Order, Invoice, Keuangan, serta Operasional. Masing-masing divisi atau sub sistem memiliki fungsi, model, serta kriteria tersendiri. Prototype sistem ini selanjutnya akan dikembangkan ke dalam bentuk final dari sistem.
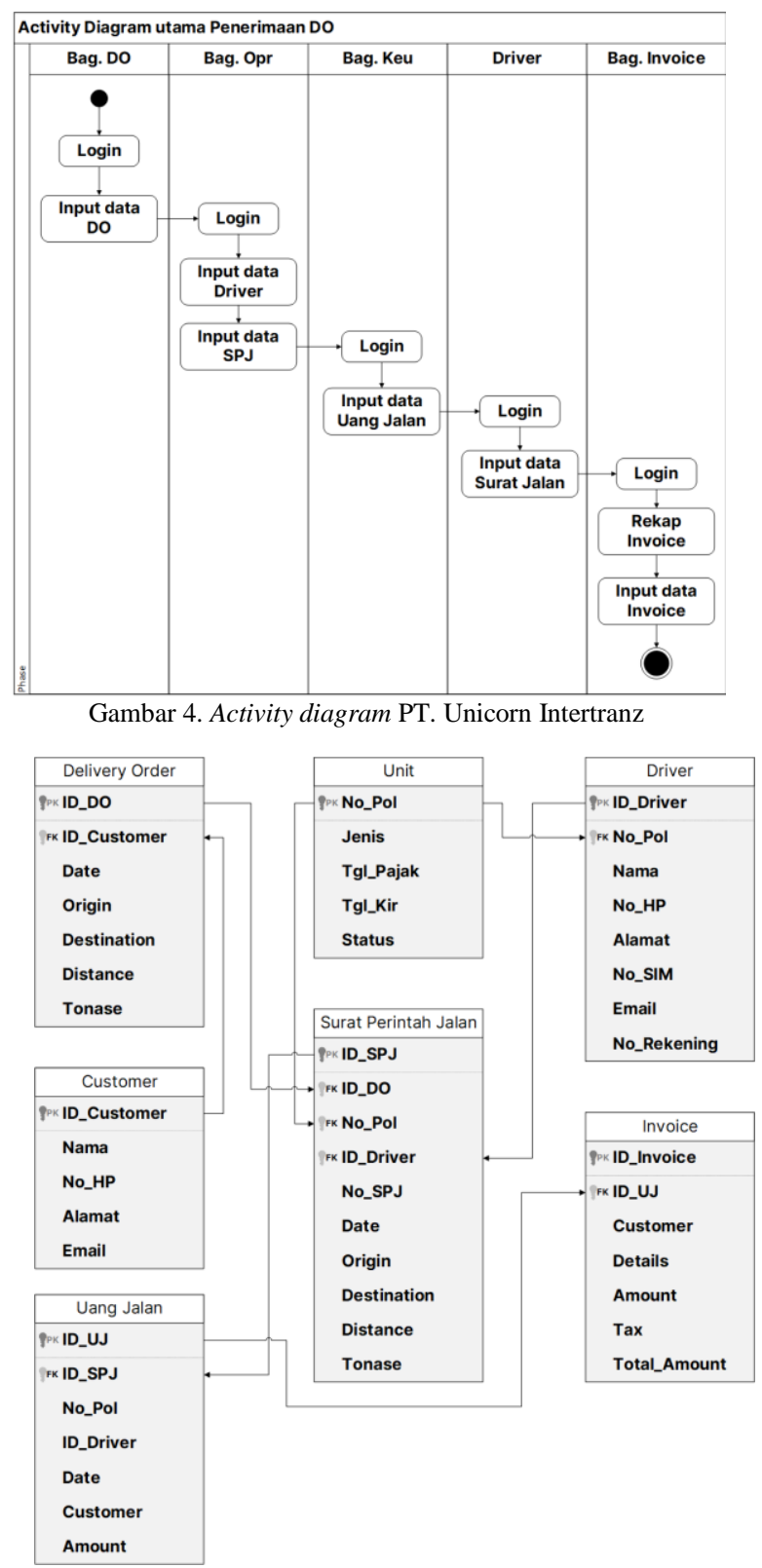

Gambar 5. Relational diagram PT. Unicorn Intertranz

1. Halaman sub sistem Delivery Order (DO)

Pada halaman ini, terdapat beberapa fungsi wajib yang harus dimiliki untuk kepentingan divisi DO seperti kemampuan sistem untuk menampilkan daftar DO aktif lengkap dengan rincian data lainnya seperti waktu keberangkatan, nama customer, hingga jumlah unit, dan halaman untuk menginput data DO dalam bentuk form. Prototype halaman ini terdapat pada gambar 6 dan 7 . 


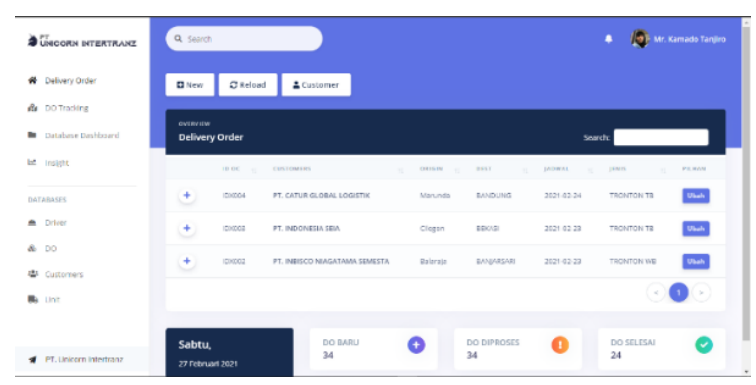

Gambar 6. Prototype halaman utama DO

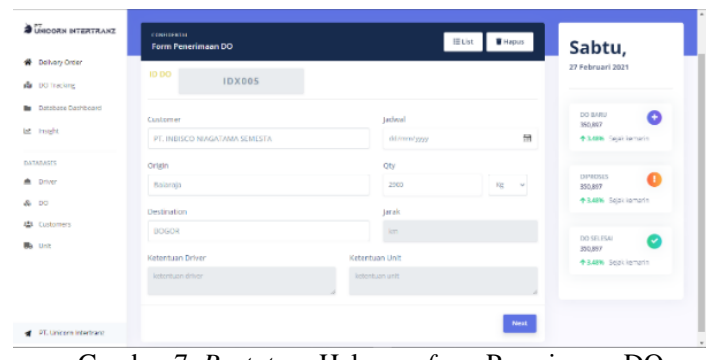

Gambar 7. Prototype Halaman form Penerimaan DO

2. Halaman sub sistem Operasional

Pada halaman ini, beberapa fungsi khusus yang perlu dikembangkan antara lain, menampilkan daftar antrean SPJ atau Surat Perintah Jalan sesuai data penerimaan DO, mampu membuat SPJ melalui form yang telah terintegrasi dengan database perusahaan. Prototipe untuk sub sistem ini dapat dilihat pada gambar 8 dan 9 .

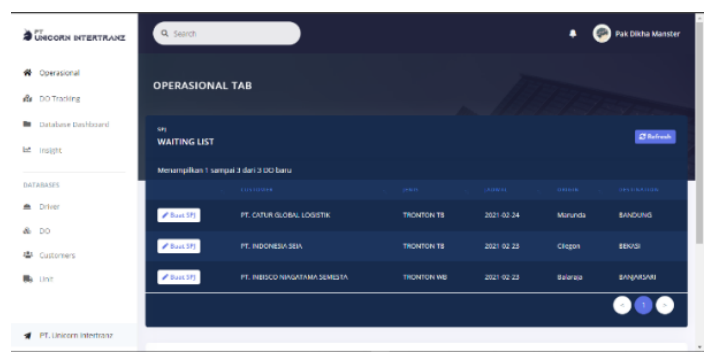

Gambar 8. Prototype halaman utama Operasional

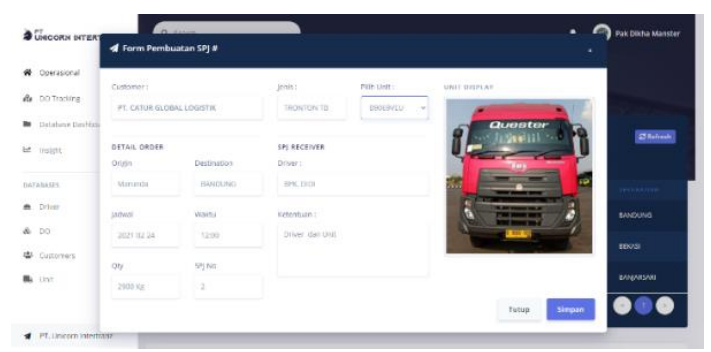

Gambar 9. Prototype Halaman form Pembuatan SPJ

3. Halaman sub sistem Keuangan

Pada halaman ini, beberapa fungsi khusus yang dikembangkan antara lain, menampilkan daftar antrean uang jalan driver sesuai SPJ yang telah terbit, serta halaman untuk menginput data uang jalan tersebut. Prototipe untuk divisi ini dapat dilihat pada gambar 10 dan 11.
4. Halaman sub sistem Invoice

Pada halaman ini, fungsi-fungsi khusus yang perlu dikembangkan antara lain, menampilkan antrean invoice customer, serta halaman form untuk publikasi invoice sebelum diberikan kepada customer. Prototipe divisi ini dapat dilihat pada gambar 12 dan 13.

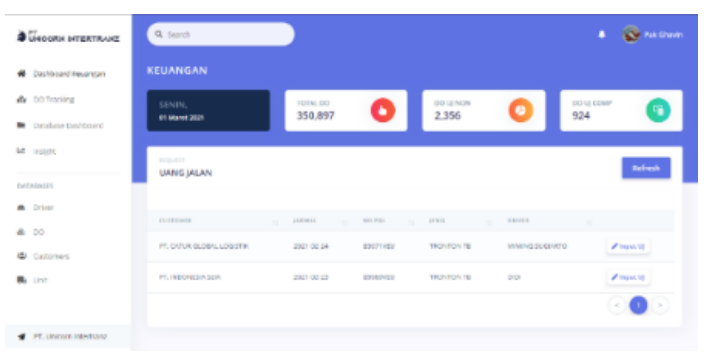

Gambar 10. Prototype halaman utama Keuangan

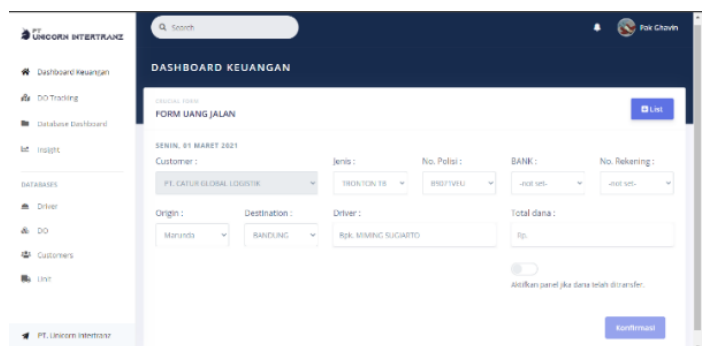

Gambar 11. Prototype Halaman form input Uang Jalan

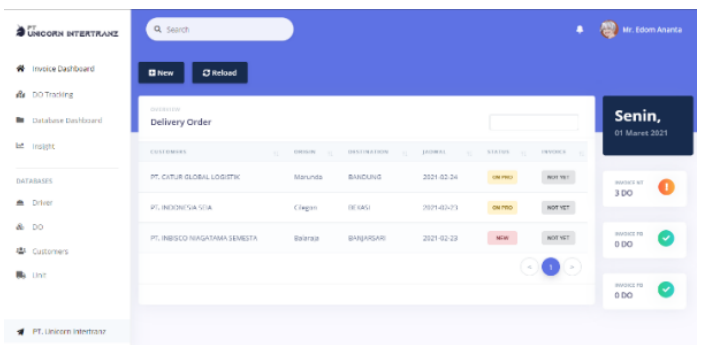

Gambar 12. Prototype halaman utama Invoice

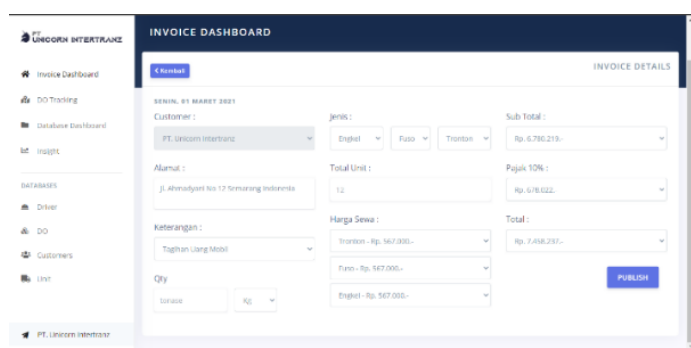

Gambar 13. Prototype Halaman form publikasi Invoice

\section{Evaluasi Prototype}

Sebelum dilakukan tahapan pengembangan final dari prototipe yang dibuat, evaluasi dan uji coba terhadap prototipe telah dilakukan dengan pihak PT. Unicorn Intertranz. Hasil evaluasi tersebut ialah,

1. Tampilan dibuat lebih menarik dan user friendly sehingga karyawan tidak merasa jenuh sewaktu mengoperasikan sistem. 
2. Beberapa tata bahasa sistem diubah sesuai kesepakatan pihak client seperti SPJ diubah menjadi SPK.

Selain evaluasi tersebut, sistem siap dikembangkan ke tahap final.

\subsection{Perancangan Akhir Sistem}

Dengan mempertimbangkan hasil evaluasi prototipe serta user requirements serta data prototipe sistem, perancangan sistem informasi manajemen PT. Unicorn Intertranz telah dibuat. Perbedaan hasil akhir sistem dengan prototipe terdapat pada tampilan sistem yang memiliki beberapa perubahan mayor pada setiap divisi namun tidak menghilangkan fungsi-fungsi utama yang telah dijabarkan pada prototipe sistem sebelumnya. Berikut hasil perancangan akhir sistem informasi manajemen PT. Unicorn Intertranz yang dikategorikan berdasarkan tiap divisi.

\section{Halaman Login}

Sebelum masuk ke dalam dashboard masingmasing divisi, karyawan perlu memasukan username dan password pada halaman ini. Routing halaman login selanjutnya diatur berdasarkan role user yang akan masuk. Antarmuka halaman login dapat dilihat pada gambar 14 .

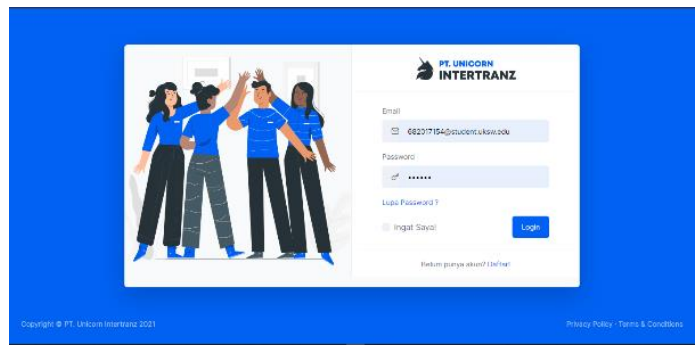

Gambar 14. Antarmuka Halaman Login

2. Halaman dashboard divisi Penerimaan DO

Merupakan halaman utama untuk divisi penerimaan DO. Dalam halaman ini terdapat form untuk inputan DO yang akan berjalan sesuai jadwal. Selanjutnya data DO yang diinputkan melalui halaman ini akan tersimpan di database dan terdistribusi ke halaman divisi-divisi lain dalam bentuk notifikasi. Antarmuka halaman daftar DO serta penerimaan DO dapat dilihat pada gambar 15 dan 16.

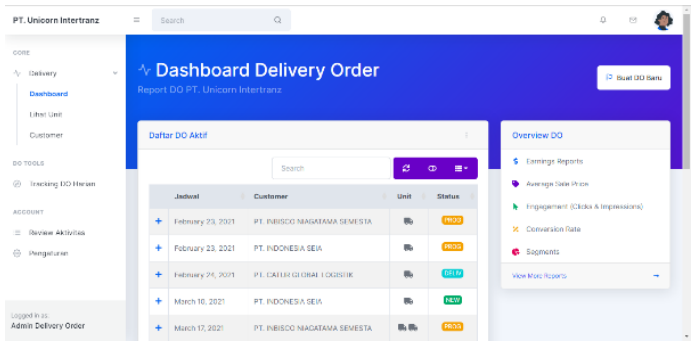

Gambar 15. Antarmuka Halaman Beranda Divisi DO.

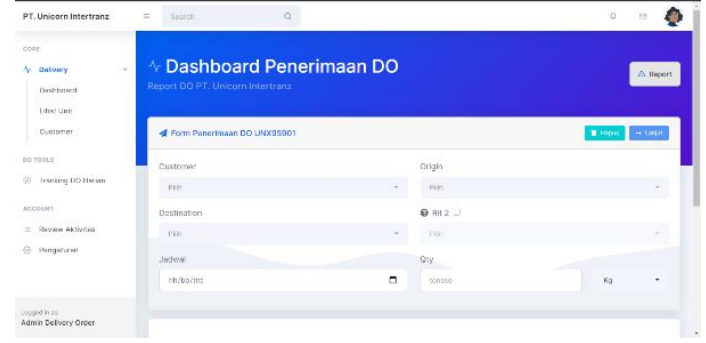

Gambar 16. Antarmuka Halaman form penerimaan DO.

3. Halaman dashboard divisi Invoice

Pada halaman ini seluruh tagihan perusahaan terhadap customer dibuat, dengan memperhatikan faktur pajak, serta tambahan biaya lainnya. Pembuatan invoice berdasar kepada customer bukan terhadap DO. Misalnya satu tagihan invoice dapat berisikan lebih dari satu DO pada perusahaan yang sama. Antarmuka halaman daftar Invoice dan form pembuatan invoice dapat dilihat pada gambar 17 dan 18.

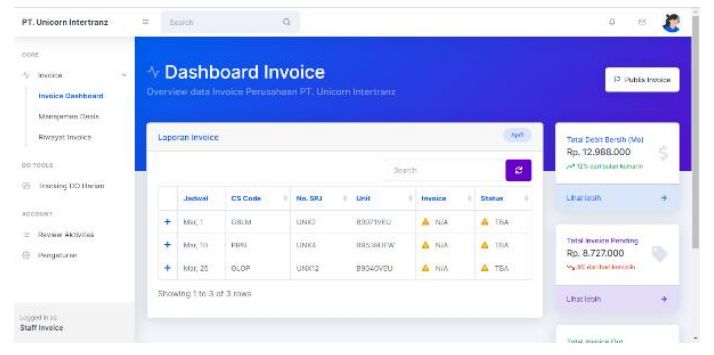

Gambar 17. Antarmuka Halaman Beranda Divisi Invoice.

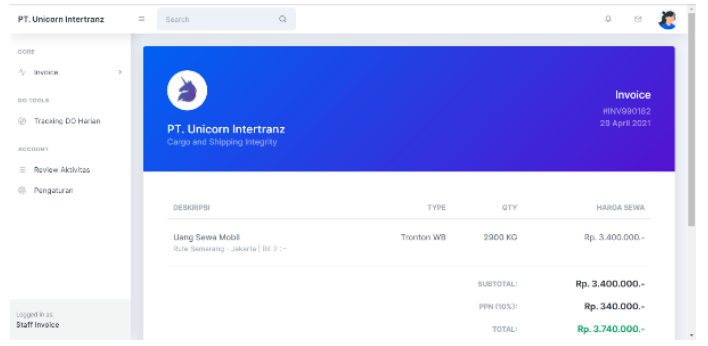

Gambar 18. Antarmuka Halaman Publikasi Invoice.

4. Halaman dashboard divisi Keuangan

Pada halaman ini seluruh data keuangan perusahaan terkumpul. Halaman ini mampu menampilkan data keuangan secara realtime, serta grafik pertumbuhan keuangan perusahaan. Halaman ini juga dapat memberikan informasi uang jalan yang diperlukan driver untuk melakukan pengantaran barang atau DO. Antarmuka halaman daftar antrean uang jalan dan form uang jalan dapat dilihat pada gambar 19 dan 20.

\section{Halaman dashboard divisi Operasional}

Halaman divisi operasional memiliki akses untuk memantau sejauh mana proses DO telah berjalan. Halaman ini juga dapat menampilkan antrean pengantaran DO sebelum mendapatkan SPK (surat pengantar kerja). 


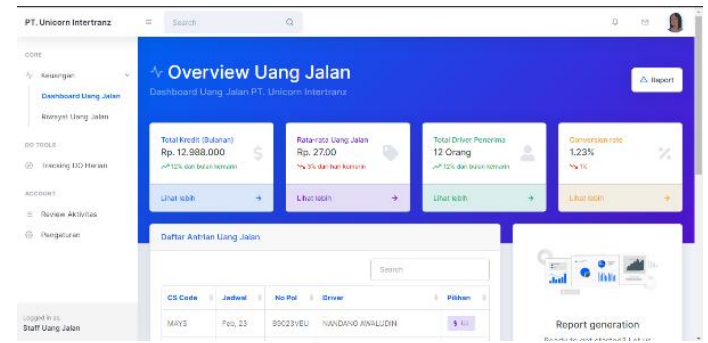

Gambar 19. Antarmuka Halaman Beranda Divisi Keuangan.

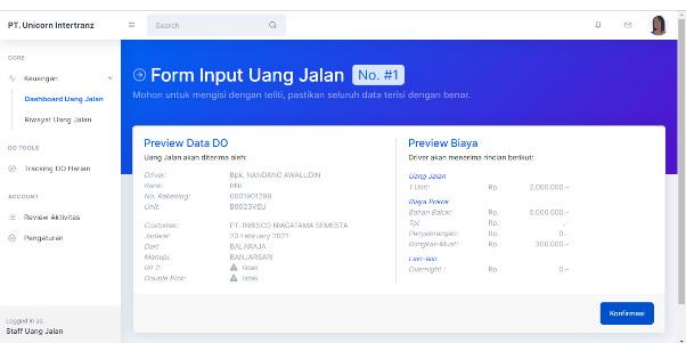

Gambar 20. Antarmuka Halaman Input data Uang Jalan.

DO yang belum memiliki SPK akan dibuatkan dan ditentukan driver serta unit sesuai kriteria pengantaran. Selanjutnya DO yang telah memiliki SPK akan diteruskan ke bagian Keuangan untuk menerima uang jalan. Antarmuka halaman antrean SPK dan form SPK dapat dilihat pada gambar 21 dan 22. Setelah itu, dilakukan pengujian sistem untuk mengetahui kualitas, menganalisis bug, serta memastikan seluruh fungsi sistem telah berjalan sesuai dengan keinginan client.
Pada tahap ini, pengujian dilakukan menggunakan metode Black Box Testing dengan membandingkan kondisi yang diharapkan dengan hasil pengujian. Metode pengujian ini diterjemahkan ke dalam beberapa tabel sesuai divisi perusahaan. Hasil pengujian dapat dilihat pada tabel-tabel berikut.

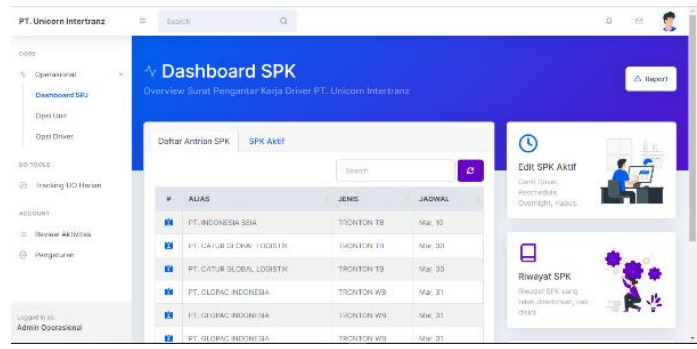

Gambar 21. Antarmuka Halaman Beranda Divisi Operasional.

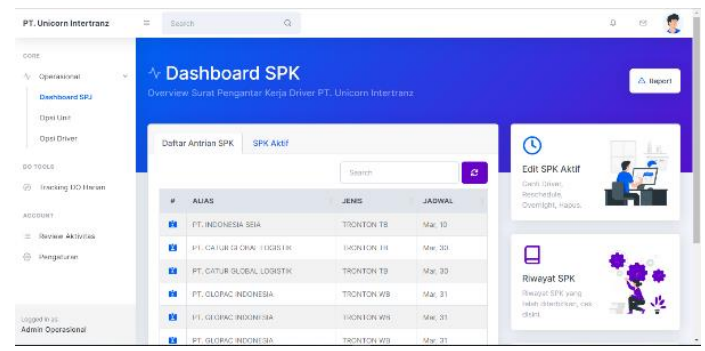

Gambar 22. Antarmuka Halaman Pembuatan SPK.

Tabel 2. Hasil Pengujian Sistem pada form divisi Penerimaan DO

\begin{tabular}{|c|c|c|c|}
\hline No. & Elemen yang diuji & Hasil yang Diharapkan & Hasil Pengujian \\
\hline 1. & Field Customer & $\begin{array}{l}\text { Menampilkan dropdown daftar customer } \\
\text { yang dapat dipilih. }\end{array}$ & $\begin{array}{l}\text { Dropdown daftar customer berhasil } \\
\text { ditampilkan ditambah field pencarian nama } \\
\text { customer. }\end{array}$ \\
\hline 2. & Field Jadwal & $\begin{array}{l}\text { Menampilkan kalender untuk memilih } \\
\text { tanggal. }\end{array}$ & $\begin{array}{l}\text { Kalender berhasil ditampilkan, tanggal bulan } \\
\text { dan tahun dapat dipilih sesuai keinginan } \\
\text { pengguna. }\end{array}$ \\
\hline 3. & Field Origin & $\begin{array}{l}\text { Menampilkan dropdown daftar origin } \\
\text { sesuai customer yang dipilih. }\end{array}$ & $\begin{array}{l}\text { Dropdown daftar origin sesuai customer yang } \\
\text { dipilih berhasil ditampilkan ditambah field } \\
\text { pencarian nama origin. }\end{array}$ \\
\hline 4. & Field Destination & $\begin{array}{l}\text { Menampilkan dropdown daftar destination } \\
\text { sesuai customer dan origin yang dipilih. }\end{array}$ & $\begin{array}{l}\text { Dropdown daftar destination sesuai customer } \\
\text { dan origin yang dipilih berhasil ditampilkan } \\
\text { ditambah field pencarian nama destination. }\end{array}$ \\
\hline 5. & Field Qty & Tidak menerima penginputan selain angka. & Tidak menerima penginputan selain angka. \\
\hline 6. & Button Next & $\begin{array}{l}\text { Menampilkan sub halaman penginputan } \\
\text { DO berisikan field penginputan jumlah } \\
\text { unit, jenis unit, dan waktu keberangkatan. }\end{array}$ & $\begin{array}{l}\text { Sub halaman penginputan DO berisikan field } \\
\text { penginputan jumlah unit, jenis unit, dan waktu } \\
\text { keberangkatan berhasil ditampilkan. }\end{array}$ \\
\hline 7. & Field masukan jumlah unit & Tidak menerima penginputan selain angka. & Tidak menerima penginputan selain angka. \\
\hline 8. & Button Input & $\begin{array}{l}\text { Membuat jumlah field jenis dan waktu } \\
\text { sesuai dengan jumlah unit yang } \\
\text { diinputkan. }\end{array}$ & $\begin{array}{l}\text { Jumlah field jenis dan waktu berubah sesuai } \\
\text { inputan yang diterima pada field jumlah unit. }\end{array}$ \\
\hline 9. & Field Jenis & $\begin{array}{l}\text { Menampilkan dropdown jenis unit yang } \\
\text { dimiliki perusahaan. }\end{array}$ & Dropdown jenis unit berhasil ditampilkan. \\
\hline 10. & Field Waktu & $\begin{array}{l}\text { Menerima inputan waktu khusus angka } \\
\text { dan tanda ': }\end{array}$ & $\begin{array}{l}\text { Tidak menerima inputan selain angka dan } \\
\text { tanda ': }\end{array}$ \\
\hline 11. & Button Back & $\begin{array}{l}\text { Menampilkan sub halaman sebelumnya } \\
\text { yakni halaman penginputan DO awal jika } \\
\text { ingin melakukan perubahan data. }\end{array}$ & $\begin{array}{l}\text { Antarmuka sub halaman sebelumnya berhasil } \\
\text { ditampilkan. }\end{array}$ \\
\hline 12. & Button Next & $\begin{array}{l}\text { Seluruh data pada fields diinputkan ke } \\
\text { dalam tabel do_harian yang ada pada } \\
\text { database, dan halaman beralih ke daftar } \\
\text { DO berjalan. }\end{array}$ & $\begin{array}{l}\text { Seluruh data pada fields berhasil diinputkan ke } \\
\text { dalam tabel do_harian yang ada pada database, } \\
\text { dan halaman beralih ke daftar DO berjalan. }\end{array}$ \\
\hline
\end{tabular}


Tabel 3. Hasil Pengujian Sistem pada form divisi Invoice

\begin{tabular}{|c|c|c|c|}
\hline No. & Elemen yang diuji & Hasil yang Diharapkan & Hasil Pengujian \\
\hline 1. & Field Customer & $\begin{array}{l}\text { Menampilkan nama customer yang telah dipilih } \\
\text { sebelumnya untuk diterbitkan invoice. }\end{array}$ & $\begin{array}{l}\text { Nama customer yang telah dipilih berhasil } \\
\text { ditampilkan. }\end{array}$ \\
\hline 2. & Field Alamat & $\begin{array}{l}\text { Menampilkan alamat sesuai customer yang dipilih. } \\
\text { Data alamat berasal dari database, tidak diinput } \\
\text { manual. }\end{array}$ & $\begin{array}{l}\text { Alamat customer sesuai pilihan user berhasil } \\
\text { ditampilkan, data alamat berasal dari } \\
\text { database customer. }\end{array}$ \\
\hline 3. & Field Keterangan & $\begin{array}{l}\text { Menampilkan keterangan berupa tagihan uang } \\
\text { mobil. }\end{array}$ & $\begin{array}{l}\text { Menampilkan keterangan berupa tagihan } \\
\text { uang mobil. }\end{array}$ \\
\hline 4. & Field Qty & Menampilkan qty sesuai DO yang ingin ditagih. & Qty sesuai DO berhasil ditampilkan. \\
\hline 5. & Field Jenis & Menampilkan jenis mobil yang disewa sesuai DO. & $\begin{array}{l}\text { Jenis-jenis mobil yang disewa berhasil } \\
\text { ditampilkan. }\end{array}$ \\
\hline 6. & Field Total Unit & $\begin{array}{l}\text { Menampilkan angka jumlah unit yang disewa pada } \\
\text { customer yang dipilih. }\end{array}$ & $\begin{array}{l}\text { Jumlah unit yang disewa berhasil } \\
\text { ditampilkan. }\end{array}$ \\
\hline 7. & Field Harga Sewa & Menampilkan harga sewa tiap unit secara terpisah. & $\begin{array}{l}\text { Harga sewa tiap unit secara terpisah berhasil } \\
\text { ditampilkan. }\end{array}$ \\
\hline 8. & Field Sub Total & $\begin{array}{l}\text { Menampilkan jumlah sub total tagihan sesuai } \\
\text { perhitungan jarak, qty, dan harga sewa. }\end{array}$ & Sub total tagihan berhasil dihitung. \\
\hline 9. & Field Pajak 10\% & Menampilkan $10 \%$ pajak dari sub total tagihan. & Pajak $10 \%$ berhasil ditampilkan. \\
\hline 10. & Field Total & Menampilkan jumlah sub total dengan $10 \%$ pajak. & $\begin{array}{l}\text { Jumlah sub total dan pajak berhasil } \\
\text { ditampilkan. }\end{array}$ \\
\hline 11. & Button Kembali & $\begin{array}{l}\text { Menampilkan halaman sebelumnya yakni halaman } \\
\text { pemilihan customer. }\end{array}$ & $\begin{array}{l}\text { Halaman pemilihan customer untuk } \\
\text { pembuatan invoice berhasil ditampilkan. }\end{array}$ \\
\hline 12. & Button Publish & $\begin{array}{l}\text { Data diinputkan pada tabel invoice di database, } \\
\text { halaman dialihkan ke daftar antrean invoice, dan } \\
\text { dokumen invoice dengan format pdf ditampilkan } \\
\text { pada halaman baru. }\end{array}$ & $\begin{array}{l}\text { Data berhasil diinputkan pada tabel invoice } \\
\text { yang ada pada database perusahaan, } \\
\text { halaman berhasil dialihkan ke daftar antrean } \\
\text { invoice dan dokumen pdf invoice berhasil } \\
\text { ditampilkan pada halaman baru. }\end{array}$ \\
\hline
\end{tabular}

Tabel 4. Hasil Pengujian Sistem pada form divisi Keuangan

\begin{tabular}{|c|c|c|c|}
\hline No. & Elemen yang diuji & Hasil yang Diharapkan & Hasil Pengujian \\
\hline 1. & Field Customer & $\begin{array}{l}\text { Menampilkan nama customer sesuai daftar antrean } \\
\text { uang jalan pada Antarmuka sebelumnya. }\end{array}$ & $\begin{array}{l}\text { Nama customer yang telah dipilih berhasil } \\
\text { ditampilkan. }\end{array}$ \\
\hline 2. & Field Jenis & $\begin{array}{l}\text { Menampilkan jenis mobil yang disewa sesuai } \\
\text { antrean uang jalan. }\end{array}$ & $\begin{array}{l}\text { Jenis mobil yang disewa berhasil } \\
\text { ditampilkan. }\end{array}$ \\
\hline 3. & Field No. Polisi & $\begin{array}{l}\text { Menampilkan nomor polisi kendaraan yang dipilih } \\
\text { sesuai antrean uang jalan. }\end{array}$ & $\begin{array}{l}\text { Nomor polisi yang sesuai berhasil } \\
\text { ditampilkan. }\end{array}$ \\
\hline 4. & Field Origin & $\begin{array}{l}\text { Menampilkan data origin sesuai pilihan pada } \\
\text { antrean uang jalan. }\end{array}$ & Data origin berhasil ditampilkan. \\
\hline 5. & Field Destination & $\begin{array}{l}\text { Menampilkan data destination sesuai pilihan pada } \\
\text { antrean uang jalan. }\end{array}$ & Data destination berhasil ditampilkan. \\
\hline 6. & Field Driver & $\begin{array}{l}\text { Menampilkan nama driver sesuai daftar antrean } \\
\text { uang jalan yang dipilih. }\end{array}$ & Data nama driver berhasil ditampilkan. \\
\hline 7. & Field Bank & Menampilkan nama bank sesuai data driver. & $\begin{array}{l}\text { Nama bank yang dimiliki driver berhasil } \\
\text { ditampilkan. }\end{array}$ \\
\hline 8. & Field No. Rekening & Menampilkan nomor rekening sesuai data driver. & $\begin{array}{l}\text { Nomor rekening yang dimiliki driver } \\
\text { berhasil ditampilkan. }\end{array}$ \\
\hline 9. & Field Total Dana & Tidak menerima inputan selain angka. & Tidak menerima inputan selain angka. \\
\hline 10. & $\begin{array}{l}\text { Radio Button Aktifkan } \\
\text { panel jika telah ditransfer. }\end{array}$ & Jika diaktifkan, tombol konfirmasi dapat dipilih. & Tombol konfirmasi dapat dipilih. \\
\hline 11. & Button List & $\begin{array}{l}\text { Menampilkan halaman sebelumnya yakni halaman } \\
\text { daftar antrean uang jalan. }\end{array}$ & $\begin{array}{l}\text { Halaman pemilihan daftar antrean uang jalan } \\
\text { berhasil ditampilkan. }\end{array}$ \\
\hline 12. & Button Konfirmasi & $\begin{array}{l}\text { Data diinputkan pada tabel uang_jalan di database, } \\
\text { halaman dialihkan ke daftar antrean uang jalan. }\end{array}$ & $\begin{array}{l}\text { Data berhasil diinputkan pada tabel } \\
\text { uang_jalan yang ada pada database } \\
\text { perusahaan, halaman berhasil dialihkan ke } \\
\text { daftar antrean uang jalan. }\end{array}$ \\
\hline
\end{tabular}

Tabel 5. Hasil Pengujian Sistem pada form divisi Operasional

\begin{tabular}{|c|c|c|c|}
\hline No. & Elemen yang diuji & Hasil yang Diharapkan & Hasil Pengujian \\
\hline 1. & Field Customer & $\begin{array}{l}\text { Menampilkan nama customer sesuai daftar antrean } \\
\text { spj yang dipilih. }\end{array}$ & $\begin{array}{l}\text { Nama customer yang telah dipilih berhasil } \\
\text { ditampilkan. }\end{array}$ \\
\hline 2. & Field Jenis & $\begin{array}{l}\text { Menampilkan jenis mobil yang disewa sesuai } \\
\text { antrean spj. }\end{array}$ & $\begin{array}{l}\text { Jenis mobil yang disewa berhasil } \\
\text { ditampilkan. }\end{array}$ \\
\hline 3. & Field Pilih Unit & $\begin{array}{l}\text { Menampilkan dropdown daftar nomor polisi } \\
\text { kendaraan yang sedang tidak dipakai sesuai jenis } \\
\text { yang diinginkan. }\end{array}$ & $\begin{array}{l}\text { Dropdown daftar nomor polisi kendaraan } \\
\text { yang sedang tidak dipakai sesuai jenis yang } \\
\text { diinginkan berhasil ditampilkan. }\end{array}$ \\
\hline 4. & Field Origin & $\begin{array}{l}\text { Menampilkan data origin sesuai pilihan pada } \\
\text { antrean spj. }\end{array}$ & Data origin berhasil ditampilkan. \\
\hline 5. & Field Destination & $\begin{array}{l}\text { Menampilkan data destination sesuai pilihan pada } \\
\text { antrean spj. }\end{array}$ & Data destination berhasil ditampilkan. \\
\hline 6. & Field Jadwal & $\begin{array}{l}\text { Menampilkan data jadwal sesuai pilihan pada } \\
\text { antrean spj. }\end{array}$ & Data jadwal berhasil ditampilkan. \\
\hline 7. & Field Waktu & Menampilkan data waktu sesuai pilihan pada & keberangkatan \\
\hline
\end{tabular}




\begin{tabular}{|c|c|c|c|}
\hline No. & Elemen yang diuji & Hasil yang Diharapkan & Hasil Pengujian \\
\hline & & antrean spj. & ditampilkan. \\
\hline 8. & Field Qty & $\begin{array}{l}\text { Menampilkan data qty sesuai pilihan pada antrean } \\
\text { spj. }\end{array}$ & Data qty berhasil ditampilkan. \\
\hline 9. & Field SPJ No. & $\begin{array}{l}\text { Menampilkan urutan SPJ yang setelah daftar SPJ } \\
\text { pada database. }\end{array}$ & Nomor Urut SPJ berhasil ditampilkan. \\
\hline 10. & Field Driver & Menampilkan nama driver sesuai unit yang dipilih. & $\begin{array}{l}\text { Nama driver berhasil ditampilkan sesuai unit } \\
\text { yang dipilih. }\end{array}$ \\
\hline 11. & Field Ketentuan & Menerima inputan semua karakter. & Menerima inputan semua karakter. \\
\hline 12. & $\begin{array}{l}\text { Container } \\
\text { Display }\end{array}$ & Menampilkan gambar unit sesuai unit yang dipilih. & $\begin{array}{l}\text { Gambar unit sesuai pilihan berhasil } \\
\text { ditampilkan. }\end{array}$ \\
\hline 13. & $\begin{array}{l}\text { Button } x \text { dan Button } \\
\text { Tutup }\end{array}$ & $\begin{array}{l}\text { Modal untuk form pembuatan SPJ ditutup, form } \\
\text { pilihan unit, nama driver, serta foto unit } \\
\text { dikosongkan. }\end{array}$ & $\begin{array}{l}\text { Modal form pembuatan SPJ berhasil ditutup, } \\
\text { jika dibuka kembali, pilihan unit, driver, } \\
\text { serta foto unit masih kosong. }\end{array}$ \\
\hline 14. & Button Simpan. & $\begin{array}{l}\text { Data diinputkan pada tabel spj di database, modal } \\
\text { form pembuatan spj ditutup. }\end{array}$ & $\begin{array}{l}\text { Data berhasil diinputkan pada tabel spj yang } \\
\text { ada pada database perusahaan, modal form } \\
\text { pembuatan spj berhasil ditutup. }\end{array}$ \\
\hline
\end{tabular}

\section{KESIMPULAN}

Sistem informasi manajemen perusahaan yang telah dibangun ini dapat digunakan untuk pengelolaan seluruh proses bisnis perusahaan mulai dari penerimaan DO, Invoice, Keuangan, hingga Operasional. Berdasarkan metode prototype, kunci utama pembangunan sistem ini ialah komunikasi. Komunikasi yang baik antar manajemen perusahaan dengan pengembang sistem mampu memberikan respons baik bagi perancangan sistem sendiri.

Perancangan sistem ini menggunakan alat bantu berupa diagram pemodelan UML (Unified Modelling Language) yang terdiri dari flowchart, use case, activity dan relational diagram. Disisi lain, kemampuan dan pemahaman bahasa pemrograman php, Ajax, Jquery, struktur database dan webserver, turut mendukung perancangan suatu sistem yang multifungsi serta dapat dikembangkan dalam jangka waktu yang singkat.

Hasil pembuatan sistem informasi manajemen perusahaan ini diharapkan mampu memberikan dampak positif serta meningkatkan efektivitas kinerja perusahaan. Sistem yang telah terintegrasi ini diharapkan mampu meminimalkan human error, serta menjadi aset tersendiri bagi perusahaan. Disisi lain, untuk menjamin kualitas dan kesesuaian fungsi sistem, dilakukan testing dengan menggunakan metode Black Box testing. Teknik ini bertujuan untuk memastikan seluruh fungsi sistem telah berjalan sesuai keinginan perusahaan, serta meminimalkan bug yang akan terjadi saat sistem resmi dipakai.

\section{DAFTAR PUSTAKA}

TOPAN, M., NAJOAN, X. B., 2015. Perancangan Sistem Informasi Manajemen Rumah sakit berbasis web. Jurnal Teknik Informatika, 6(1).

MASRUR, M., MUSTOFA, N. A., \& SOFANNI, M., 2015. Rancang Bangun Sistem Informasi Pengelolaan Kendaraan di PT PLN (Persero) Area Mojokerto. Register: Jurnal Ilmiah Teknologi Sistem Informasi, 1(1), 24-36.
OGEDEBE, P. M., \& JACOB, B. P., 2012. Software Prototyping: A Strategy to Use When User Lacks Data Processing Experience. ARPN Journal of Systems and Software. VOL. 2, NO.6, 2012.

MULYANI, S., 2017. Sistem Informasi Manajemen Rumah Sakit: Analisis dan Perancangan. Abdi Sistematika.

HIMAWAN, H., SAEFULLAH, A., \& SANTOSO, S., 2014. Analisa dan Perancangan Sistem Informasi Penjualan Online (E-Commerce) pada CV Selaras Batik Menggunakan Analisis Deskriptif. Scientific Journal of Informatics, 1(1), 53-63. 
Halaman ini sengaja dikosongkan 